\title{
Nephroprotective effect of ethanolic leaf extract of Thaumatococcus danielli (benth.) in streptozotocin induced diabetic rats
}

\author{
Olubukola Sinbad Olorunnisola ${ }^{1, *}$, Adewale Adetutu ${ }^{1}$, Rasaq B. Popoola ${ }^{1}$, Abiodun \\ Olusoji Owoade ${ }^{1}$, Peter Adegbola ${ }^{1}$, Babatunde T. Adesina ${ }^{2}$
}

${ }^{1}$ Biochemistry Department, Ladoke Akintola University of Technology, Ogbomoso Oyo State Nigeria; ${ }^{2}$ Department of Animal Science, College of Agricultural Sciences, Landmark University, Ipetu Road, Omu-Aran, Kwara State, Nigeria

Corresponding author: Olubukola Sinbad Olorunnisola, $\mathrm{PhD}$, Biochemistry Department, Ladoke Akintola University of Technology, Ogbomoso Oyo State Nigeria

Submission Date: March $30^{\text {th }}$, 2017, Acceptance Date: December $27^{\text {th }}$, 2017, Publication Date: December $31^{\text {st }}, 2017$

Citation: Olorunnisola O.S., Adetutu A., Popoola R.B., Owoade A.O., Adegbola P., Adesina B.T., Nephroprotective effect of ethanolic leaf extract of Thaumatococcus danielli (benth.) in streptozotocin induced diabetic Rats. Functional Foods in Health and Disease 2017; 7(12): 923935. https://doi.org/10.31989/ffhd.v7i12.349

\begin{abstract}
Background: The leaves of Thaumatococcus danielli (Benth.) have been traditionally used in folk medicine to treat malaria in Nigeria. However, there is no report on whether these leaves contain Nephroprotective activity. Thus, the ethanol leaf extract was investigated for Nephronprotective activity in Streptozotocin induced diabetic rats.
\end{abstract}

Methods: First, the $\mathrm{LD}_{50}$ of the leaf was determined using standard procedure. Rats were assigned to 5 groups (A-E) of five rats. Except for the control group, each group was made diabetic using Streptozotocin $(65 \mathrm{mg} / \mathrm{kg} / \mathrm{b} . w t$. i p). The treated groups received $0.5 \mathrm{ml}$ of glibenclamide (25 mg/kg/b.wt, o.p), 250 and $500 \mathrm{mg} / \mathrm{kg} / \mathrm{b} . w \mathrm{t}$, o.p of Thaumatococcus danielli respectively. After 14 days of treatment, animals were sacrificed under light anaesthesia. Data expressed as Means \pm S.D $(n=5)$ and was analyzed using one-way ANOVA followed by Dunnet's test. Values were considered significant at $\mathrm{p}<0.05$.

Results: The plant showed a $\mathrm{LD}_{50}$ greater than $5000 \mathrm{mg} / \mathrm{kg} / \mathrm{b}$.wt in albino rats observed for 72 hours. A significant $(\mathrm{p}<0.05)$ decrease in serum $\mathrm{Na}^{+}, \mathrm{Cl}^{-}, \mathrm{HCO}_{3}^{-}$, total protein, and an insignificant increase in $\mathrm{K}^{+}$, urea and creatinine level were observed in the diabetic group when compared with the normal group. Oral administration of plant extract and glibenclamide significantly $(\mathrm{p}<0.05)$ restored the electrolytes to near normal. Histological alterations such as 
glomerulonephritis and tubules infiltration by inflammatory cells observed in diabetic control were also reversed.

Conclusion: This study suggests renal protective ability of the plant against impairment due to hyperglycemia.

Keywords: Streptozotocin, Thaumatococcus danielli, Nephroprotective, Glibenclamide, serum electrolytes.

\section{INTRODUCTION}

Diabetes mellitus (DM) is a metabolic disorder characterized by derangements in carbohydrates, lipids, fat, and oil metabolism. The disease can be caused by the autoimmune destruction of pancreas beta-cells, peripheral insulin resistance, or down regulation of insulin receptors in peripheral cells [1]. DM has been implicated in several serious health problems including glomerulonephritis, nephropathy, retinopathy, hepatopathy, and cardiomyopathy, all of which can increase the risk of death [2]. Therefore, early control and regular medication can help improve a patient's life span and prevent these complications.

The majority of chemotherapeutic drugs commonly employed for the management of DM have been reported to have many side effects [3] such as diarrhea. Some of these effects may increase plasma levels of homocysteine, which is a very significant risk factor for cardiovascular disease. Fortunately, a promising new approach has emerged: herbal medicine. Herbal medicine involves the use of natural products and synthetic agents, either alone or in combination, to prevent diabetes in humans with supposed little to no side effects. According to Ervin et al.'s [4] survey report, $40-60 \%$ of diabetic patients use conventional treatments, with $23 \%$ of these patients using botanicals. The approach was also corroborated by WHO (1989) General Assembly [5]. The use of herbal medicines for diabetes management is also encouraged due to the belief that it has some advantages over orthodox medicine, thereby allowing users to feel more in control in their choice of medication [6]. T. danielli is a plant species from West Africa, being a medicinal plant of great importance. It is commonly used in folk medicines to cure or manage a wide range of diseases, including insanity and pulmonary problems, in addition to being used as a laxative, sedative, and for the treatment of diabetes in the Western part of Nigeria [7]. Ethno pharmacological studies demonstrate the use of these plants in the management of diabetes [36]. Diabetes is generally believed to be accompanied with oxidative stress [33]. This oxidative stress is associated with the pathogenesis of several diseases, including renal failure. Diabetic nephropathy (DN) is one of the major microvascular complications of diabetes mellitus, with its development being confirmed through significant enhancement in the level of blood urea nitrogen (BUN), glycated serum protein (GSP), and serum creatinine (Scr) [34]. The antidiabetic study on $T$. danielli in alloxan induced diabetic rats conducted by Emudainohwo et al. [32] revealed the significant potential of the plant as a new source of hypoglycemic drug, while failing to address the possible protective role of the plant on renal functions often impaired in diabetes. With this backdrop, we investigated the nephron-protective effect of leaf extract of Thaumatococcus danielli in Streptozotocin induced diabetes rats. Additionally, an in-vitro study on the pancreas protective activity of the flavonoid and phenolic extracts from the leaves of $T$. danielli shows potent activity through its Fe (II) chelating and radical scavenging abilities [37]. 
The essential oil of the plant demonstrated significant inhibitory effect on selected microbial strains in an in-vitro study conducted by Adeola et al. [38]. Phytochemical studies demonstrated high contents of terpenoids, flavonoids, alkaloids, and tannins [39]. In-vitro studies have shown that flavonoids have anti-inflammatory, anti-allergic [40], antimicrobial [41], anticancer [42], and hypolipidemic effects [43]. Furthermore, terpenoids and flavonoids have been reported with potent antioxidant, hypolipidemic, and organ protective activity [35]. Pharmacological investigation has revealed the antioxidant efficacy of the plant, which might contribute to its efficacy in preventing oxidative stress induced diabetes complications such as nephron-toxicity. Additionally, the potential of $T$. danielli to perform these pharmacological functions may be due to the presence of some phytochemical compounds such as terpenoids, flavonoids, alkaloids, and cardiac glycosides [8]. The presence of these phytochemicals in T. danielli confirms its potential in medicinal use. Presently, only a few studies have been conducted on the anti-diabetic and organ protective activities of the plant. Therefore, the present study was designed to evaluate the nephron-protective effect of ethanol leaf extracts of the previously mentioned plant in Streptozotocin-induced diabetic rats.

\section{MATERIALS AND METHODS \\ Plant Collection and Authentication}

Fresh leaves of the Thaumatococcus danielli (Benth.) plant were obtained from the local market, rightly opposite the King's Palace, Oja Igbo, Ogbomoso, Oyo State, Nigeria in the month of May, 2015. The plant was identified and authenticated by a Taxonomist, Dr A.T.J. Ogunkunle, of the Herbarium unit of Pure and Applied Biology Department, Ladoke Akintola University of Technology, Ogbomoso, Oyo State, and a voucher specimen (LHO 448) was deposited.

\section{Preparation of Plant Extract}

Fresh leaves of $T$. danielli were rinsed with tap water, air dried under shade for two weeks, and then grinded to a powder using the Emel electrical blender (model no. EM-2815). Four hundred grams (400 g) of the blended plant was macerated and extracted with $99 \%$ ethanol using soxhlet extractor for 72 hours at room temperature. The yield of the ethanol was found to be $10.82 \%$ $\mathrm{w} / \mathrm{w}(132 \mathrm{~g})$. The extract was later concentrated under reduced pressure and refrigerated at $4^{\circ} \mathrm{C}$ for further use.

\section{Chemicals and Reagents}

Electrolytes $\left(\mathrm{Na}^{+}, \mathrm{K}^{+}, \mathrm{Cl}^{-}\right.$and $\left.\mathrm{HCO}^{-}\right)$, creatinine, and urea kits used for this study were obtained from Randox Laboratories United Kingdom. Other reagents and chemicals were of analytical grade. Streptozotocin, citrate buffer, chloroform, distilled water, ethanol, formaldehyde, glibenclamide, glucose, olive oil, and plant extract. All chemicals and drugs used were obtained commercially and of analytical grade. Streptozotocin was purchased from (Sigma chemical Company St. Louis U.S.A.).

\section{Experimental Animals}

Wistar albino female Rats, 7-8 weeks old, with an average weight of $180.0 \mathrm{~g}$, were obtained from the Department of Anatomy, Ladoke Akintola University of Technology, Ogbomoso, Oyo State, Nigeria. Animals were housed under standard conditions of temperature $\left(22 \pm 2^{\circ} \mathrm{C}\right)$ and relative 
humidity (30-70\%) with a 12:12 light:dark cycle. They were allowed to acclimatize to the laboratory environment for a period of two weeks before the commencement of the experiment. Animals were kept on a standard rat pellet diet and provided water ad libitum. The study was carried out after approval from the Departmental Ethical Committee on Use and Care of Experimental Animals, Department of Biochemistry, Faculty of Basic medical sciences, College of Health sciences, Ladoke Akintola University of Technology. The animals were handled humanely in accordance with the guidelines of the European Convention Protection for Vertebrate Animals and Other Scientific Purposes-ETS-123 (European Treaty Series, 2005).

\section{Acute toxicity test}

The acute toxicity test of the ethanol leaf extract of $T$. danielli was determined using the up and down method described by Lorke [9]. Five (5) rats of both sexes were used for this study. After 7 days of acclimatization, the rats were fasted overnight, with free access to water prior to dosing. The rats were weighed and dosed with a limit dose of $5000 \mathrm{mg} / \mathrm{kg}$ body weight of the freshly prepared ethanol extracts of $T$. danielli. The rats were monitored for 72 hours for any change in behavior. The rats survived the highest dose; hence, it was concluded that the $\mathrm{LD}_{50}$ of the plant extract is greater than $5000 \mathrm{mg} / \mathrm{kg}$.

\section{Induction of Diabetes Mellitus}

The animals were fasted for 16-18 hours with free access to water prior to the induction of diabetes. Diabetes was induced by a single intraperitoneal injection of Streptozotocin (Sigma St. Louis, M.S., U.S.A.) at a dose of $65 \mathrm{mg} / \mathrm{kg}$ body weight, dissolved in $0.1 \mathrm{M}$ Citrate buffer (pH 4.5) [10]. The rats were then kept for the next 24 hours on $5 \%$ glucose solution bottles in their cages to prevent hypoglycemia [11]. 72 hours after Streptozotocin treatment, blood glucose was measured using a glucometer, and rats having a fasting blood glucose level greater than 180 $\mathrm{mg} / \mathrm{dL}$ were considered as diabetic and were included for the study [12].

\section{Experimental Design}

Twenty-five Wistar albino female Rats with an average weight of $180 \mathrm{~g}$ were used for this study. After induction of diabetes, the animals were randomly assigned into five groups (A-E) of five rats each.

Group A: Normal control group was given $1 \mathrm{ml}$ of normal saline orally

Group B: Diabetic controls were administered with $0.5 \mathrm{ml}$ of distilled water orally.

Group C: Diabetic rats treated with $25 \mathrm{mg} / \mathrm{kg}$ body weight of Glibenclamide orally

Group D: Diabetic rats treated with $250 \mathrm{mg} / \mathrm{kg} / \mathrm{b}$.wt of $T$. danielli orally.

Group E: Diabetic rats treated with $500 \mathrm{mg} / \mathrm{kg} / \mathrm{b}$.wt of T.danielli orally.

All treatments were given once daily for a period of 14 days.

\subsection{Sample Collection for Analysis}

Twelve hours after the last feeding and administration (overnight fast), the animals were euthanized under chloroform vapor and dissected. Whole blood obtained by cardiac puncture into non-heparinized tubes were allowed to clot for $1 \mathrm{~h}, 30 \mathrm{mins}$, and afterwards centrifuged (4000 $\mathrm{g}$ for $10 \mathrm{mins}$ ) to remove cells and recover serum for the biochemical assays. The kidneys 
were surgically removed and de-capsulated then cleansed of blood with $0.25 \mathrm{M}$ sucrose solution and afterwards fixed in $10 \%$ formaldehyde.

\section{Biochemical Assays}

Electrolyte $\left(\mathrm{Na}^{+}, \mathrm{K}^{+}, \mathrm{Cl}^{-}\right.$and $\left.\mathrm{HCO}_{3}^{-}\right)$, creatinine, urea, and total proteins were estimated according to the manufacturer's instruction on the assay kits.

\section{Histopathological Study}

The fixed kidney tissues were sectioned (5-micron thickness) and sections stained with Hematoxylin and Eosin (H\&E) according to the Conn [13] procedure and photomicrographs were developed (x 400).

\section{Statistical Analysis}

Data were expressed as Means \pm S.D $(n=5)$. The results were analyzed using one-way ANOVA followed by Dunnet's test to compare the diseased and the treated groups. At the same time, the statistical difference between the normal and diseased was analyzed by an unpaired $t$-test. The results were considered statistically significant, if $\mathrm{p}<0.05$.

\section{RESULTS}

\section{Acute toxicity test}

The experimental rats treated with an acute dose of $5000 \mathrm{mg} / \mathrm{kg} / \mathrm{body}$ weight of the ethanol leaf extract of $T$. danielli demonstrated no change in physical activity and no apparent toxicity symptoms or mortality up to 72 hours post treatment. Therefore, it was concluded that the $\mathrm{LD}_{50}$ of the ethanol crude extract of the plant in rats is greater than $5000 \mathrm{mg} / \mathrm{kg} / \mathrm{body}$ weight.

\section{Effect of the extract and the standard on serum electrolyte status in diabetic rats}

Table 1 revealed that serum $\mathrm{Na}^{+}, \mathrm{Cl}^{-}, \mathrm{HCO}_{3}{ }^{-}$, and total protein decreased significantly $(\mathrm{p}<0.05)$ while creatinine and urea concentration increased insignificantly $(\mathrm{p}<0.05)$ in diabetic rats (Group B) compared with the normal control group (Group A). Oral administration of $5 \mathrm{mg} / \mathrm{kg} / \mathrm{bw} . \mathrm{t}$ Glibenclamide (C), $250 \mathrm{mg} / \mathrm{kg} / \mathrm{bw} . t$ (D), and $500 \mathrm{mg} / \mathrm{kg} / \mathrm{bw} . t$ of $T$. danielli (E) to animals significantly $(\mathrm{p}<0.05)$ restored the deranged electrolytes to near normal. The activities of extracts were dose dependent and more pronounced at $500 \mathrm{mg} / \mathrm{kg}$. At this concentration (500 $\mathrm{mg} / \mathrm{kg} / \mathrm{bw} . \mathrm{t})$, the activities of the extract compared favorably with the standard drug.

Table 1: Ameliorative effects of Thaumatococcus danielli and Glibenclamide standard on renal damage in Streptozotocin (STZ)-Induced diabetic rats treated.

\begin{tabular}{|c|c|c|c|c|c|c|c|}
\hline Group & $\mathbf{K}^{+}$ & $\mathbf{N a}^{+}$ & $\mathrm{Cl}^{-}$ & $\mathrm{HCO}_{3}{ }^{-}$ & Total protein & Urea & Creatinine \\
\hline A & $5.30 \pm 0.61$ & $155.00 \pm 4.02$ & $106.00 \pm 6.33$ & $31.52 \pm 0.50$ & $7.50 \pm 0.11$ & $38.30 \pm 0.66$ & $10.23 \pm 0.23$ \\
\hline B & $5.99 \pm 0.64$ & $106.70 \pm 4.74 *$ & $84.55 \pm 1.94 *$ & $21.89 \pm 0.22 *$ & $3.90 \pm 0.21$ & $40.81 \pm 0.25 \#$ & $12.47 \pm 0.13 \#$ \\
\hline $\mathrm{C}$ & $5.44 \pm 0.62$ & $135.32 \pm 4.43$ & $101.23 \pm 5.65$ & $29.45 \pm 1.20$ & $6.93 \pm 0.33$ & $35.94 \pm 0.10$ & $11.46 \pm 0.55$ \\
\hline D & $5.65 \pm 0.97$ & $130.11 \pm 6.46$ & $98.59 \pm 7.75$ & $29.91 \pm 0.11$ & $5.24 \pm 0.16$ & $37.34 \pm 0.12$ & $13.66 \pm 0.23$ \\
\hline $\mathbf{E}$ & $5.42 \pm 0.45$ & $140.20 \pm 10.43$ & $99.30 \pm 5.74$ & $28.44 \pm 0.24$ & $6.34 \pm 0.29$ & $36.10 \pm 0.23$ & $1097 \pm 0.52$ \\
\hline
\end{tabular}

Values are Mean $\pm \mathrm{SD}, \mathrm{n}=5$. *Values are significantly different from the normal control group at $(\mathrm{p}<0.05){ }_{\text {insignificant difference from the normal control }}$ 


\section{Effect of the extract on kidney architecture in diabetic rats}

Histopathological observations showed normal kidney architecture in group A, C, D, and E (Figure 1, 3, 4, 5). In contrast, with group B the diabetic control demonstrated increased Bowman's capsular space, through infiltration of glomerulus and tubules by inflammatory cells.

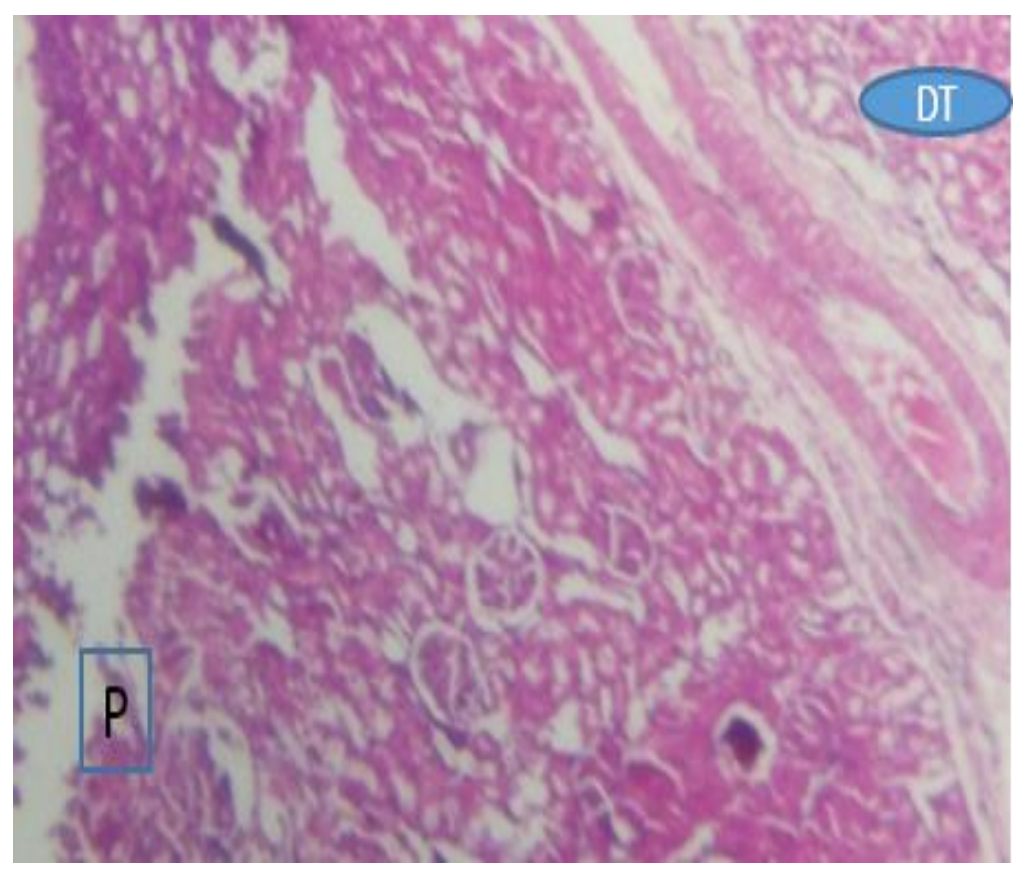

Figure 1. Photomicrograph of normal rat kidney showing no lesion. The black thick line represents normal glomeruli, blue line represents normal proximal tubule while the white represents normal distal tubule. (H\& E 400X)

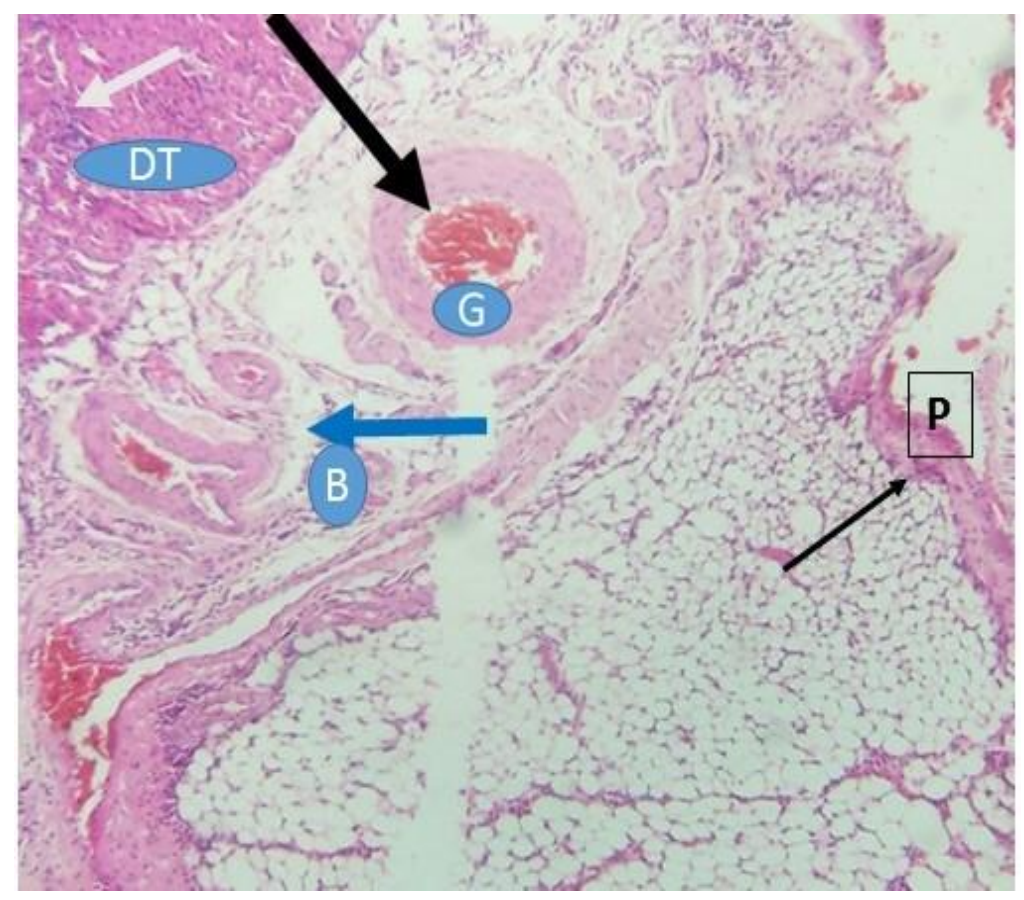

Figure 2. Photomicrograph of kidney of diabetic rats showing glomeruli (G) (Black thick arrow) and tubules (P) (Thin black arrow) infiltrated by inflammatory cells and increased Bowman's capsular space (Blue thick arrow) (B) (H\& E 400X). 


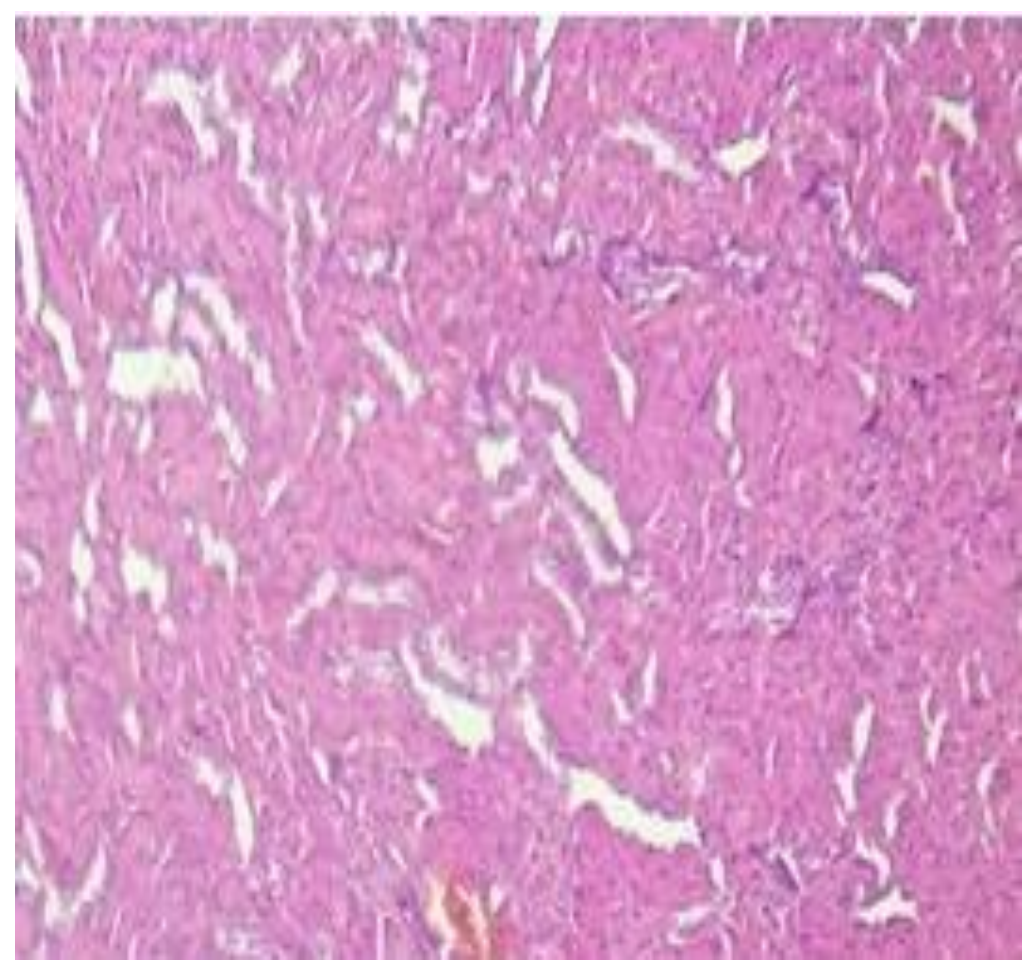

Figure 3. Photomicrograph of Diabetic rat kidney treated with $25 \mathrm{mg} / \mathrm{kg} / \mathrm{b}$.wt of glibenclamide showing tissue with closely packed renal tubules, no inflammatory cells, no necrosis (H\& E 400X).

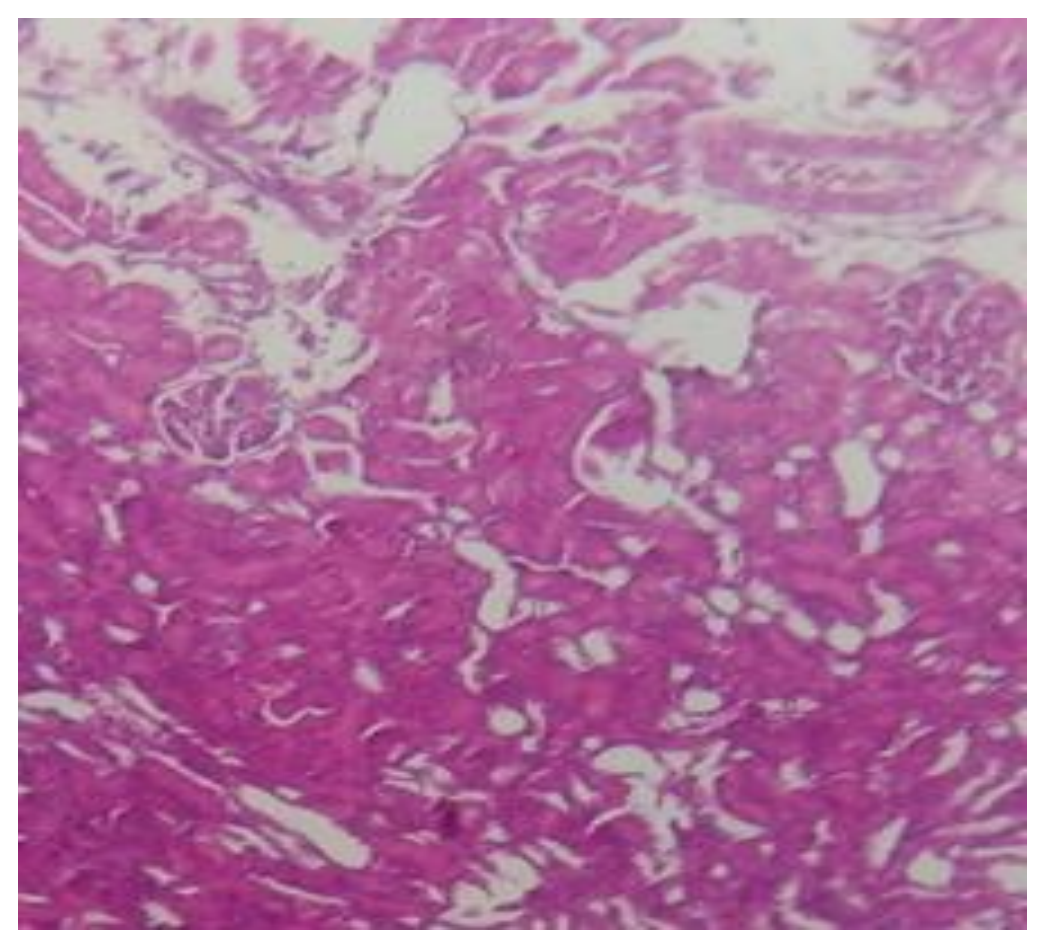

Figure 4. Photomicrograph of diabetic rat kidney treated with $250 \mathrm{mg} / \mathrm{kg} / \mathrm{bw} . \mathrm{t}$ extract of Thaumatococcus danielli's showing tissue with closely packed renal tubules, no inflammatory cells, no necrosis (H\& E 400X). 


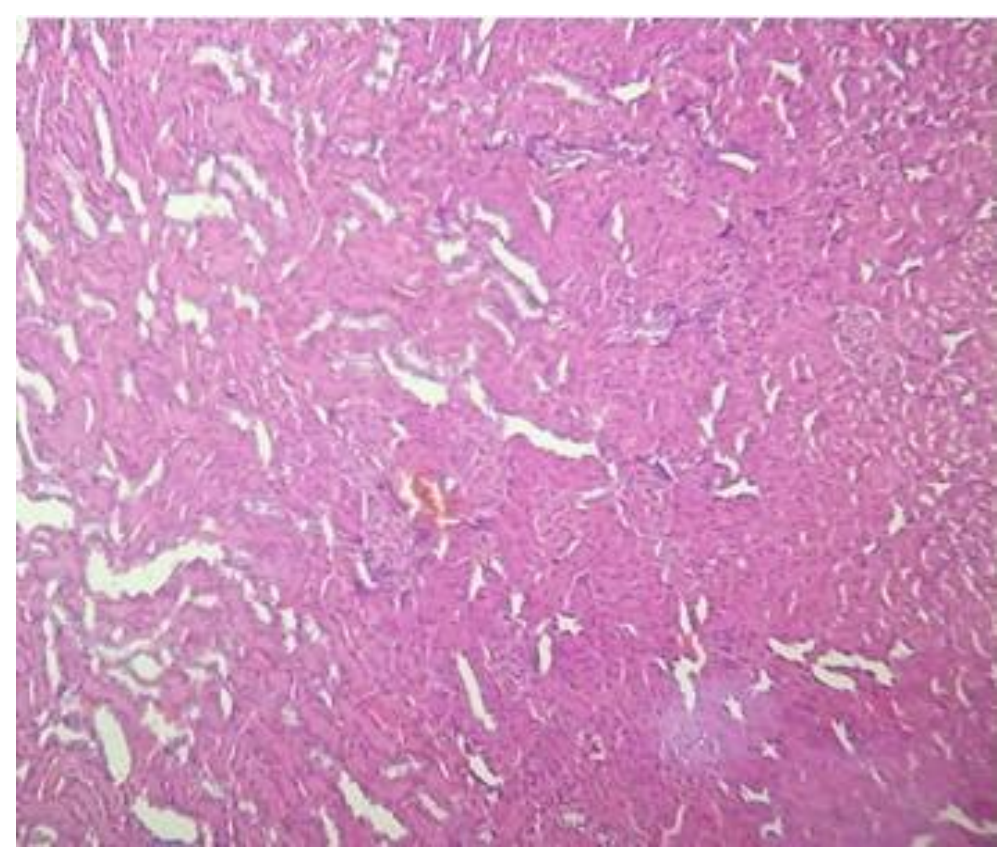

Figure 5. Photomicrograph of diabetic rat kidney treated with $500 \mathrm{mg} / \mathrm{kg} / \mathrm{b}$.wt extract of Thaumatococcus danielli's showing tissue with closely packed renal tubules, no inflammatory cells, no necrosis (H\& E 400X).

\section{DISCUSSION}

Uncontrolled hyperglycemia has been reported to alter electrolyte balance [14]. It has been postulated that hyperglycemia induced osmotic diuresis leads to severe loss of electrolytes such as sodium, potassium, calcium, chloride, and phosphates [15]. The observed decrease in serum sodium and chloride ion in the diabetic control (untreated) in the present study (Table 1) is consistent with the report of Ikip et al. [16], Prohp and Onoagbe [17], and Yakubu and Nwodo [18]. The reason for the alteration in serum levels of the electrolytes in Streptozotocin-induced diabetic rats was numerous. For example, Adesokan et al. [19] and Yakubu and Nwodo [18] suggested that it may be due to renal function impairment. On the other hand, Eteng et al. [15] speculated it may be due to hypoglycemia induced osmotic diuresis, accompanied with the marked urinary loss of water and electrolytes. It may also be aggravated by urinary excretion of ketones which involved additional electrolyte loss. Furthermore, decreased serum $\mathrm{Na}^{+}$ion level may also be due to the translocation of $\mathrm{Na}^{+} \mathrm{K}^{+}$-ATPase pumps from the basolateral membrane of proximal convoluted tubules to the cytosol which resulted in a decrease in sodium pumping from renal tubules to the blood [20]. Additionally, the expression of sodium channel proteins in the collecting ducts and distal convoluted tubules was altered, leading to an increased fractional excretion of sodium in urine. The mechanism follows in tandem for chloride ion, which is known to have similar cellular transmembrane transport.

However, Oral administration of $T$. danielli extract significantly reversed the decrease in the serum sodium ion level in a dose dependant manner (Table 1) when compared with the diabetic group, and this suggested that the plant extract might contain an anti-hyperglycemic agent, which removes glucose from blood and urine, thereby preventing dehydration. It could also mean that the plant extract has a healing effect on the kidney [21] and this may be due to it phytochemical constituents such as flavonoids [22]. Furthermore, there is also the possibility that this extract 
might increase the uptake of glucose by peripheral tissue and thereby presumably decreased the serum glucose level.

Changes in the potassium level in the serum usually should alternate those of sodium [23]. Diabetic acidosis is prominent in most diabetes and it usually leads to decreased potassium excretion in urine; thus, there was an increased retention in serum [24]. The insignificant increase in serum $\mathrm{K}^{+}$in the diabetic untreated group in this investigation may be due to the extracellular migration of ion in response to acidosis [18]. Oral treatment of the extract at the doses of $250 \mathrm{mg}$ and $500 \mathrm{mg} / \mathrm{kg}$, in the present investigation, resulted in a slight modification of such electrolyte imbalance in a dose dependant manner.

The reduction in plasma bicarbonate observed in this study is also in support of diabetic acidosis. This is due to the ketone body losing a proton (in diabetic condition); it circulates in the blood and lowers blood $\mathrm{pH}$. The proton (hydrogen ions) released from ketone is buffered by plasma bicarbonate [25].

The insignificant increase in Urea and creatinine levels in the diabetic control when compared to the control group may suggest moderate impaired renal function which is most likely to be asymptomatic [26]. We therefore hypothesize that the deficiency of insulin, an anabolic hormone, and inability of glucose to reach the extra hepatic tissues (which then induces gluconeogenesis as an alternate route of glucose supply) [27], may be responsible for the slight insignificant increase in serum Urea and creatinine. More so, Atangwho et al. [28], reported that hyperuricemia may be from deamination of glucogenic amino acids which were released from increased proteolysis. Additionally, the slight, insignificant increase in creatinine level in the untreated diabetic group could be attributed to the decreased body weight and reduced muscle mass [29].

Oral administration of the extracts insignificantly reversed this condition. This is in line with our earlier suggestion that the anti-hyperglycaemic effect of the plant may be responsible for reduction in serum glucose concentration and consequently the reintroduction of insulin effect, thereby leading to proteolysis reclines via hormonal stimulation [27]. This study suggests that the extract of $T$. danielli, apart from reducing high blood glucose levels in blood, may also improve the basal metabolic rate and electrolyte profile.

The significant $(\mathrm{p}<0.05)$ reduction in total protein observed in the diabetic untreated group in the present study is consistent with the previous report. According to Khan and Miungwana [30], hyperglycemia increased protein catabolism, accompanied with the increased transport of amino acids in the liver, for the purpose of gluconeogenesis leading to accelerating ureagenesis, resulting in hypo-proteinemia and hypoalbuminemia. However, treatment with the extract restored the total protein concentration to near normal in a dose and time dependent manner. The activity of the plant compared favorably with the standard drug, suggesting that the extract may have a similar mechanism of action.

As expected, photomicrographs of the kidneys of diabetic untreated rats (Figure 2) demonstrated glomeruli and tubules infiltrated by inflammatory cells and nephritis, which were reversed following the standard and extract treatment respectively (Figure 3, 4, and 5). The pathological changes observed in the diabetic rats (Figure 2) were induced by the oxidative stress associated with diabetes. Jimoh and Odutaga [31] had reported alterations and disintegration of the glomeruli of the kidneys due to the free radicals generated by thermo-oxidized lipids. It is likely that these pathological changes led to disruption, infiltration, and concentration of urine, in 
addition to the fluid and electrolyte balance, as was observed from biochemical assays. The plant extract might contain biochemical agents that reversed the impressed factor responsible for hyperglycemia induced oxidative stress. Thus, a corrective measure even on the histology of the kidney was noticed.

\section{CONCLUSION}

This study validates the traditional use of Thaumatococcus danielli and suggested that the plant might contain biochemical agents, which could protect the kidney against impairment due to diabetes.

List of Abbreviations: DM, Diabetes mellitus; WHO, World Health Organization; STZ, Streptozotocin; SD, Standard deviation.

Authors' Contributions: OSO, AA and AOO participated in the study design, OSO, AA, RBP PA and BTA performed the experiments, OSO provided the reagents, AOO provided the rats, OSO, AA, PA and RBP analyzed and interpreted the results, OSO, RBP and PA wrote the manuscript. All authors read and approved the final manuscript.

Competing Interests: We wish to state categorically that there is no existing conflict of interest with respect to this study.

Acknowledgements and Funding: The authors declare the study received no funding from any organization whatsoever.

\section{REFERENCES}

1. Santhan JM, Zuber AM: Evaluation of anti-diabetic and nepheroprotective activity of 95\% ethanolic extract of canthium diococcum whole plants by using albino rats. $\mathrm{J}$ Chem Pharmacol Toxicol 2013m 3: 1-10.

2. Behnam-Rassouli M, Ghayour MB, Ghayour N: Microvascular Complications of Diabetes. Journal of Biological Sciences 2010, 10: 311-423

3. Abbasi F, Chu JW, McLaughlin T, Lamendola C, Leary ET, Reaven GM: Effect of metformin treatment on multiple cardiovascular disease risk factors in patients with type 2 diabetes mellitus. Metabolism 2004, 53: 159-164.

4. Ervin RB, Wright JD, Kennedy-Stephenson J: Dietary supplements in the United States, 1988- 94. Vital Health Statistics 2004, 1999: 1-14.

5. Dey L, Attele A, Yuan CS: Alternative therapies for type II Diabetes. Altern Med Res 2002, 7: 45-58.

6. Joshi BS, Kaul PN: Alternative medicine: Herbal drugs and their critical appraisalPart I. Prog Drug Res 2001, 56: 1-76.

7. Lim TK: Edible Medicinal and Non-Medicinal Plants: Volume 3, Fruits. Springer Science Business Media BV; 2012.

8. Shalom NC, Adetayo YO, Samuel TP, Bolaji JD, Tamunotonyesia E: Analyses of the leaf, fruit and seed of Thaumatococcus daniellii (Benth): Exploring potential uses. Pakistan journal of Biological Science 2014, 17(6): 849-854. 
9. Lorke D: A New Approach to Tropical Acute Toxicity Testing. Arch Toxicol 1983; 53: $275-287$.

10. Katsumata KY, Katsumata TO, Katsumata K: Potentiating Effects of combined usage of three sulphonylurea Drugs on the occurrence of Alloxan-induced Diabetes in rats. Horm Metab Res 1999, 25:125-126.

11. Dhandapani S, Ramasamy SV, Rajagopal S, Namasivayam N: Hypolipidemic effect of Cuminumcyminum L. on alloxan-induced diabetic rats. Pharmacol Res 2002, 46(3): 251-255.

12. Stanley AMP, Venugopal MP: Anti-oxidant action of Tinosporacordifolia root extract in alloxan diabetic rats. Phytother Res 2001, 15: 213-218

13. Conn HJ: Biological Stains: A handbook on the nature and uses of the dyes employed in the biological laboratory. 5ed ed. Biotech publication; 1946: 98.

14. Item JA, Patrick EE, Godwin EE, Ime FA: Effects of Co-administration of Extracts of Vernonia amygdalina and Azadirachta Indica on Serum Electrolyte Profile of Diabetic and non-Diabetic Rats. Australian Journal of Basic and Applied Sciences 2009, 3(3): 2974-2978

15. Eteng MU, Ibekwe HA, Essien AD Onyeama HP: Effects of Catharanthus roseus on Electrolyte Derangement induced by Chlopropamide (Diabinese) $\mathrm{R}$ on Normoglycemic Albino Wistar Rat. BioRes 2008, 6(2): 364-366.

16. Ikpi DE, Obembe AO, Nku CO: Aqueous leaf extract of Rothmannia longiflora improves basal metabolic rate and electrolyte parameters in alloxan induced diabetic rats. Nigerian Journal of Physiological Sciences 2009, 24(1): 67 - 71.

17. Prohp TP, Onoagbe IO: Plasma electrolyte concentrations in normal and streptozotocin induced diabetic rats treated with extracts of Triplochiton scleroxylon K. Schum. America Journal of Research Communication 2014, 2(5):154-174

18. Yakubu OE, Nwodo OFC: Histopathological examination and changes in serum electrolytes in Streptozotocin-induced diabetic rats owing to treatment with ethanol extract of Vitex doniana leaves. International Journal of Pharma Sciences and Research 2015, 6(5): 830-835.

19. Adesokan AA, Oyewole OI, and TurayBabara MS: Kidney and Liver Function Parameters in Alloxan-Induced Diabetic Rats Treated with Aloe Barbadensis Juice Extract. Sierra Leone Journal of Biomedical Research 2009, 1(1): 33-37

20. Fogh-Andersen N, McNair P, Mgller-Petersen J, Madsbad S: Serum Calcium Fractions in Diabetes Mellitus. Clinical Chemistry 1982, 28: 2073-2076.

21. Ayelagbe OG, Adel AS: Effect of Allium Cepa Supplemented Diets on Plasma Glucose, Electrolytes and Renal Histology of Streptozotocin-Induced Diabetic Rats. IOSR Journal of Pharmacy and Biological Sciences (IOSR-JPBS) 2015, 10(4): 2532.

22. Emudainohwo JOT, Erhirhie EO, Moke EG, Ejebe DE: Hypoglycemic Effect of Ethanol Leaf Extract of Thuamatococus Daneilli (ELETD) In Alloxan Induced Diabetic Wistar Rats. J of Pharmacy and Bio Sci 2015, 10 (1-2): 59-64.

23. Loeb S: Clinical Laboratory Test; Values and Implication. Copyright, Springhouse Corporation, Springhouse Pennsylvania; 1991. 
24. Nduka N: Clinical Biochemistry for Student of Chemical Pathology. $1^{\text {st }}$ Edn. Lagos: Longman Nigeria Plc; 1997.

25. Berman PTP: Lecture 6: Carbohydrates metabolism and diabetes, Chemical Pathology Lecture Note, 2011: 191-125.

26. Peiris HLG, Chandrasena, RD, Laneroll RD: Serum cystatin c as a marker to identify patients with moderately impaired renal function, Indian Journal of Clinical Biochemistry 2008, 23(2): 163-166

27. Robinson G, Johnson DE: Metabolic Disorder; Diabetes in Mechanisms of Disease. An Introduction to clinical science. $1^{\text {st }}$ Edn, Cambridge; Cambridge University Press 1997

28. Atangwho UE, Eyong E, Obi A: Effect of Vernonia amygdalina Del Leaf on Kidney Function of Diabetic Rats. IJP 2007, 143-148.

29. Blann A: Routine blood tests 1: why do we test for urea and electrolytes? Nursing Times 2014, 110(5): 19-21.

30. Khan RM, Miungwana SM: 5-Hydroxylapachol: a cytotoxic agent from Tectona grandis. Phytochemistry 1999, 50: 439-442.

31. Jimoh FO, Odutaga AA: Histology changes of selected rat tissues following the ingestion of thermally oxidized groundnut oil. Biochemistry 2004, 16: 1-10.

32. Emudainohwo JOT, Erhirhie EO, Moke EG, Ejebe DE: Hypoglycemic Effect of Ethanol Leaf Extract of Thuamatococus Daneilli (ELETD) In Alloxan Induced Diabetic Wistar Rats. Journal of Pharmacy and Biological Sciences 2015, 10(2): 5964.

33. Mohankumar SK, O'Shea T, McFarlane JR: Insulin otrophic and insulin-like effects of a high molecular weight aqueous extract of Pterocarpus marsupium Roxb Hardwood. J Ethnopharmacol 2012, 141:72-79.

34. Ahmed D, Kumar V, Verma A, Gupta PS, Kumar H, Dhingra V, Mishra V, Sharma M: Anti-diabetic, renal/hepatic/pancreas/cardiac protective and antioxidant potential of methanol/dichloromethane extract of Albizzia Lebbeck, Benth. stem bark (ALEx) on streptozotocin induced diabetic rats. BMC Complementary and Alternative Medicine 2014, 14(243): 4-17.

35. Sudhakumari Anil KH, Aamir J, Manish J, Muralidhar ST: Cardioprotective Effects in Methanolic Extract of Evolvulus Alsinoides Linn on Isoproterenol-Induced Myocardial Infarction in Albino Rats. International Journal of Basic Medical Sciences and Pharmacy (IJBMSP) 2012, 2: 53-57.

36. Olorunnisola OS, Adetutu A, Owoade AO, Okoh OO, Oyewo EB, Adegbola P: Ethno-pharmacological and in-vitro anti-diabetic study of some medicinal plants commonly used in Ogbomoso, South Western Nigeria. J. Appl. Biosci 2016, 105: 10064-10084.

37. Oboh G, Akinyemi AJ, Oyeleye IS, Williams K: Protective effect of phenolic extracts from two species of miracle berry leaves (Thaumatococcus daniellii and Megaphrynium macrostachyum) on some pro-oxidant induced oxidative stress in rat pancreas in vitro. Journal of Applied Pharmaceutical Science 2016, 6 (01): 118-124.

38. Adeola AS, Folorunso OS, Akintobi TA: Assessment of Antibacterial Activity of Essential Oil Extracted from Leaves of Thaumatococcus danielli (Benn.) Benth. in 
Light of its Inhibitory Impact on Extracellular Protease of Shigella dysenteriae. International Journal of Biochemistry Research \& Review 2015, 5(1): 9-19.

39. Chinodu SN, Oluwadamisi AY, Popoola ST: Analyses of the leaf, fruit and seed of Termaumatococcus daniellii (Benth): Exploring Potential use. Parkistan Journal of Biological Sciences 2014, 17(6): 849-854.

40. De-sousa RRR, Queiroz ACS, Sousa SA, Augusto et al.: Phosphoprotein levels, MAPK activities and NFKB expression are affected by fisetin J. Enzyme Inhibition Med Chem 2007, 22: 439-444

41. Cushnie TP, Lamb AJ: Antomicrobial activity of flavonoids. Int J Antimicrob Agents 2005, 26: 343-356.

42. Yamamoto Y, Gaynor RB: Therapeutic potential of inhibition of the NF-KappaB pathway in the treatment of inflammation and cancer. J Clin Invest, 2001, 107:135142.

43. Sudheesh SG, VIijayakumar PS, Vijayalakshmi NR: Hypolipidemic effect of flavonoids from solanum melogena. Plant food, Human Nutr, 1997, 51:321-330. 